\title{
NOTE
}

\section{Presence of Panulirus argus Virus 1 (PaV1) in juvenile spiny lobsters Panulirus argus from the Caribbean coast of Mexico}

\author{
Juan Pablo Huchin-Mian ${ }^{1}$, Rossanna Rodríguez-Canul ${ }^{1, *}$, Efraín Arias-Bañuelos ${ }^{1}$, \\ Raúl Simá-Álvarez ${ }^{1}$, Juan A. Pérez-Vega' ${ }^{1}$, Patricia Briones-Fourzán², \\ Enrique Lozano-Álvarez ${ }^{2}$
}

\begin{abstract}
${ }^{1}$ Laboratorio de Inmunología y Biología Molecular, Centro de Investigación y de Estudios Avanzados del Instituto Politécnico Nacional, Unidad Mérida, Km. 6 Antigua Carretera a Progreso, CORDEMEX, Mérida, Yucatán 97310, México

${ }^{2}$ Universidad Nacional Autónoma de México, Instituto de Ciencias del Mar y Limnología, Unidad Académica Puerto Morelos, Ap. Postal 1152, Cancún, Quintana Roo 77500, México
\end{abstract}

\begin{abstract}
Macroscopic evidence, histological sections, transmission electron microscopy (TEM) evaluation, and PCR analyses of 25 apparently diseased juvenile spiny lobsters Panulirus argus from the reef lagoon of Puerto Morelos, Mexico, showed the presence of Panulirus argus Virus 1 (PaV1). Cowdry Type A intranuclear viral inclusions were observed in histological analyses, icosahedral viral particles were observed by TEM, and PCR using specific primers for PaV1 amplified a fragment of $499 \mathrm{bp}$. This is the first report of PaV1 infecting P. argus outside the Florida Keys, USA.
\end{abstract}

KEY WORDS: Spiny lobster · Panulirus argus $\cdot$ PaV1 $\cdot$ Cowdry Type A intranuclear inclusions

Resale or republication not permitted without written consent of the publisher

\section{INTRODUCTION}

In 2004, Panulirus argus Virus 1 (PaV1) was first reported in Caribbean spiny lobsters Panulirus argus (Latreille, 1804) from the Florida Keys, USA (Shields \& Behringer 2004). This virus is highly pathogenic to juvenile lobsters as shown by a mortality of $100 \%$ within 30 to $80 \mathrm{~d}$ in experimentally induced infections. Prior to death, infected lobsters show lethargy, morbidity, 'milky' hemolymph, lack of hemolymph coagulation, and suppression of molt. The virus infects hemocytes, primarily hyalinocytes and semigranulocytes, and spongy connective tissue cells producing eosinophilic Cowdry Type A intranuclear viral inclusions (Shields \& Behringer 2004, Li \& Shields 2007). The virus is icosahedral in shape (mean size \pm SD: $182 \pm$ $9 \mathrm{~nm}$ ) by transmission electron microscopy (TEM) and shares some morphological features from the families Herpesviridae and Iridoviridae (Shields \& Behringer 2004). As PaV1 is highly prevalent in juveniles of $P$. argus and owing to the wide distribution of these lobsters throughout the Caribbean region, its propagation could have a potentially significant impact on $P$. argus fisheries.

We report the first record of PaV1 in spiny lobsters Panulirus argus from the Mexican Caribbean.

\section{MATERIALS AND METHODS}

Twenty-five juvenile Panulirus argus (17.9 to $50.3 \mathrm{~mm}$ carapace length) showing macroscopic signs similar to those reported in juveniles from Florida infected with PaV1 (Shields \& Behringer 2004) were collected in June 2006 from the reef lagoon of Puerto Morelos on the Caribbean coast of Mexico $\left(20^{\circ} 51^{\prime} \mathrm{N}\right.$, $86^{\circ} 53^{\prime} \mathrm{W}$, Fig. 1). After collection, lobsters were transported to the laboratory within $1 \mathrm{~h}$ and were immediately dissected. Tissue samples from hepatopancreas, gills, and muscle of the 25 lobsters were fixed for $48 \mathrm{~h}$ in Davidson's solution (22\% formaldehyde, 33\% ethanol, $11.5 \%$ glacial acetic acid, and $33.5 \%$ distilled 


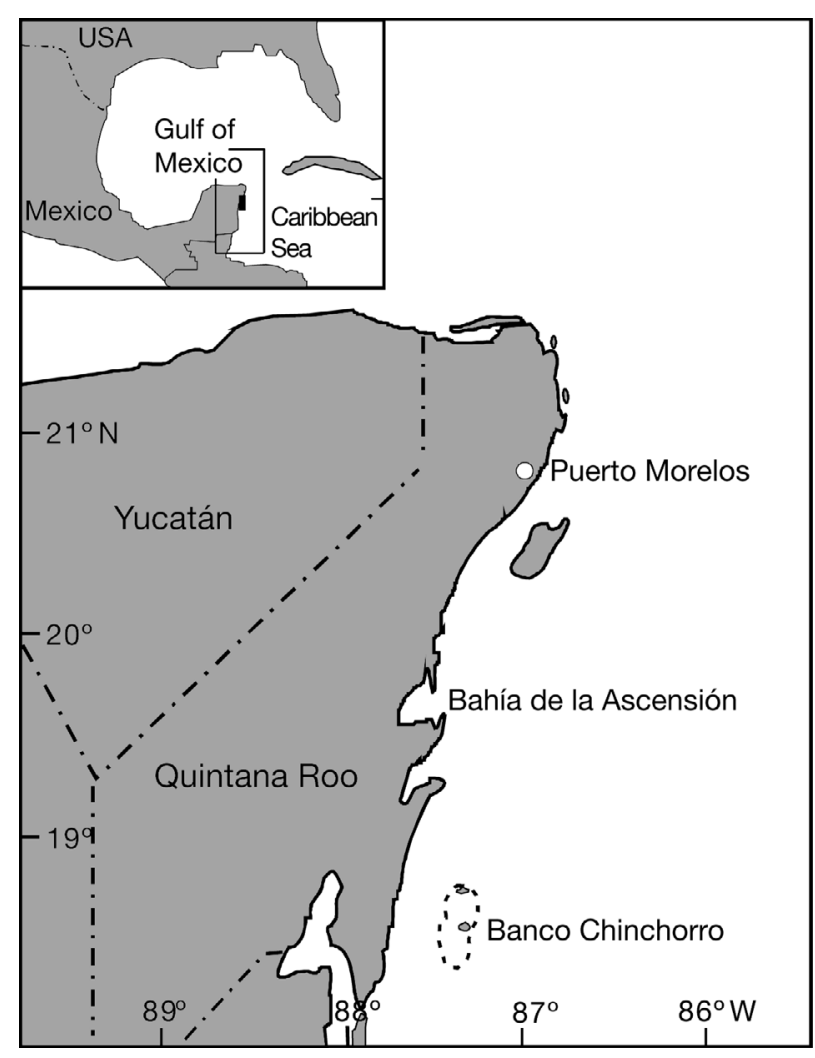

Fig. 1. Panulirus argus collection site (O)

water) and processed by a routine histological method followed by hematoxylin and eosin (H\&E) stains (Lightner 1996). Stained sections were observed under a standard light microscope to examine histopathological changes and the images were captured using a digital camera (Evolution ${ }^{\mathrm{TM}}$ LC Color). The severity of infection of each tissue type was estimated using the numerical scale of Bell \& Lightner (1987), who assigned infection severity grades from 0 to 4 based on the estimated number of diagnostic Cowdry Type A intranuclear inclusions (CAI) per microscopic field(s) at $40 \mathrm{X}$ : Grade 0 = no CAI observed; Grade $1=1-5$ CAI $/ 200$ fields; Grade $2=1-2 \mathrm{CAI} / 20$ fields; Grade 3 = 1-5 CAI/2 fields); and Grade $4>10 \mathrm{CAI} /$ field.

For the TEM examinations, the hepatopancreas of 8 lobsters were first fixed in $2.5 \%$ glutaraldehyde with $0.2 \mathrm{M}$ sodium cacodylate buffer, then in $1 \%$ osmium tetraoxide and further dehydrated in increased serial dilutions of ethanol. Finally, samples were mounted in Spurr's resin. Ultra-thin sectioned samples placed on grids were processed through a routine lead citrate stain and observed with a Jeol microscope (JEM-1200 EX II) (Reynolds 1963).

Fifteen lobsters were used for the PCR analysis. Genomic DNA were extracted from $\sim 25 \mathrm{mg}$ of hepatopancreatic tissue using the wizard ${ }^{\circledR}$ genomic DNA purification kit (Promega ${ }^{\circledR}$ ) according to the manufacturer's protocol. The primers specific for PaV1 45aFTCCAGCCCAGGTACGTATC and 543aR-AACAGATT-TTCCAGCAGCGT that amplify a region of $499 \mathrm{bp}$ were used after a modification of the original protocol of Montgomery-Fullerton et al. (2007). All PCR reactions were carried out in a total volume of $25 \mu \mathrm{l}$ containing $\sim 32.5 \mathrm{ng}$ of DNA, $0.33 \mu \mathrm{M}$ of each primer, $2.5 \mathrm{mM}$ of $\mathrm{MgCl}_{2}, 1.2 \times$ reaction buffer $(50 \mathrm{mM} \mathrm{KCl}$, 10 mM Tris- $\mathrm{HCl}, \mathrm{pH} 9.0,0.1 \%$ Triton X-100), $0.4 \mathrm{mM}$ dNTPs mixture (Promega ${ }^{\circledR}$ ), and $2.5 \mathrm{U}$ of Taq DNA polymerase (Promega ${ }^{\circledR}$ ). Reactions were run on a thermal cycler (TECHNE TC-312) at $94^{\circ} \mathrm{C}$ for $10 \mathrm{~min}$, followed by 30 cycles of $94^{\circ} \mathrm{C}$ for $30 \mathrm{~s}, 63^{\circ} \mathrm{C}$ for $30 \mathrm{~s}$, and $72^{\circ} \mathrm{C}$ for $1 \mathrm{~min}$, with a final extension of $72^{\circ} \mathrm{C}$ for $10 \mathrm{~min}$. PCR products were electrophoresed on $2 \%$ agarose gels and bands were visualized using $0.1 \%$ ethidium bromide stain on a UV transilluminator. DNA from lobsters collected in the Reef lagoon of Puerto Morelos showing increasing signs of morbidity and with a Grade 4 infection in the hepatopancreas were used as positive controls, whereas sterile water and DNA from the hepatopancreas of adult lobsters collected at the same sampling site and diagnosed as negative to PaV1 by histology and by lack of signs of morbidity were used as negative controls.

\section{RESULTS}

Cowdry Type A intranuclear inclusions were detected in histological samples of hepatopancreas, gill, and muscle tissues. All hepatopancreatic tissue slides

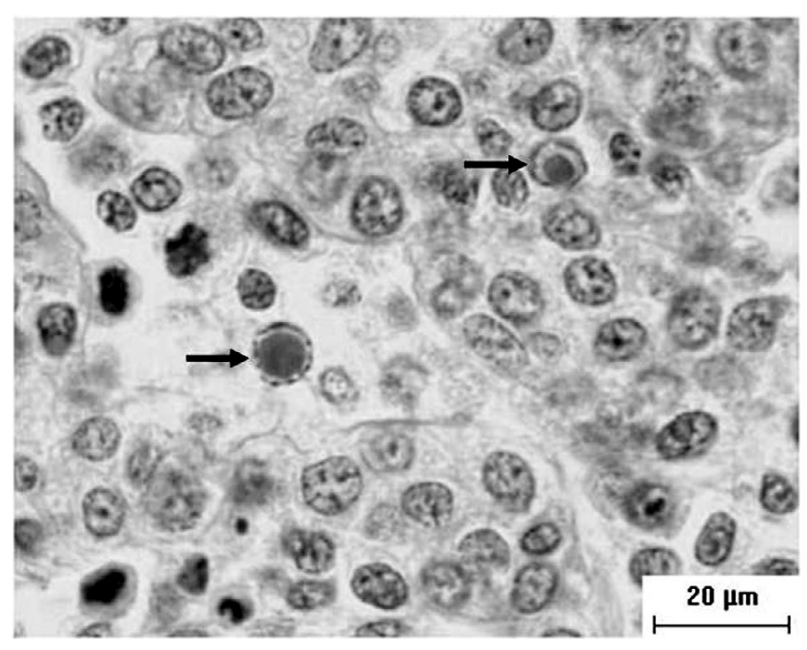

Fig. 2. Panulirus argus. Light micrograph of spiny lobster hepatopancreas showing infected cells (arrows) within the hemal sinus with eosinophilic Cowdry Type A inclusions, emarginated condensed chromatin, and hypertrophied nuclei (H\&E). Scale bar $=20 \mu \mathrm{m}$ 


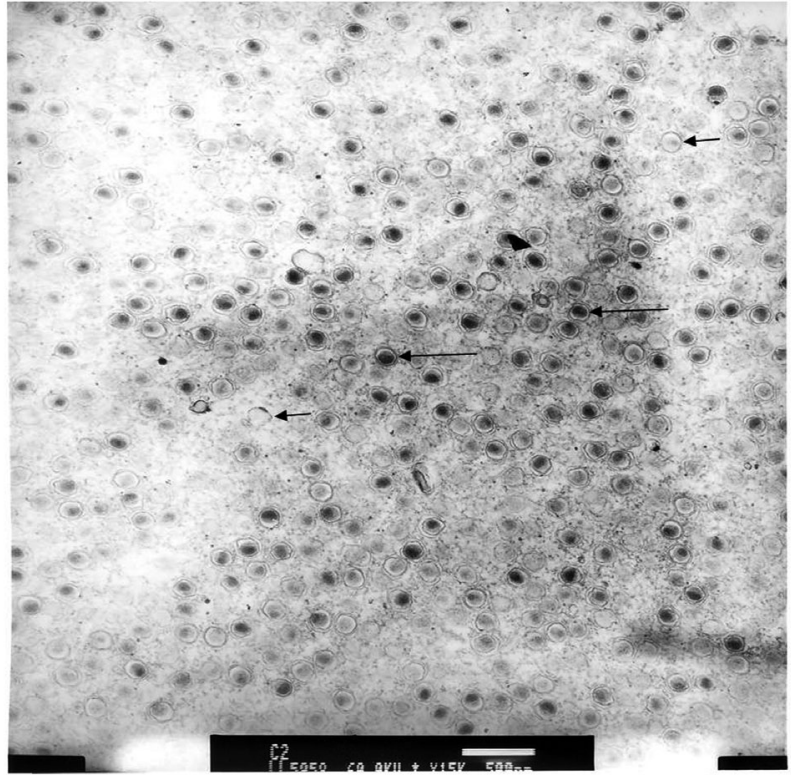

Fig. 3. Panulirus argus. Electron micrograph of hepatopancreas of lobster infected with $P$. argus Virus 1 (PaV1), showing empty capsids (short arrows) and nucleocapsids (large arrows). White scale bar $=500 \mathrm{~nm}$

demonstrated a Grade 4 infection severity by histopathology. In contrast, sections of gills (5 CAI/ field) and muscle (2 CAI/field) were found to have Grade 1 infections. All the viral inclusions were characterized by nuclear hypertrophy and condensed chromatin on the nuclear membrane (Fig. 2). The TEM analysis showed icosahedral viral particles, with bilayered capsule, empty capsids, and some particles containing electrondense toroids, presumably nucleoids (Fig. 3). The molecular analysis of suspected infected tissues showed amplification at the $499 \mathrm{bp}$ region specific for PaV1. Fig. 4 shows an example of PCR results in 15 infected lobsters.

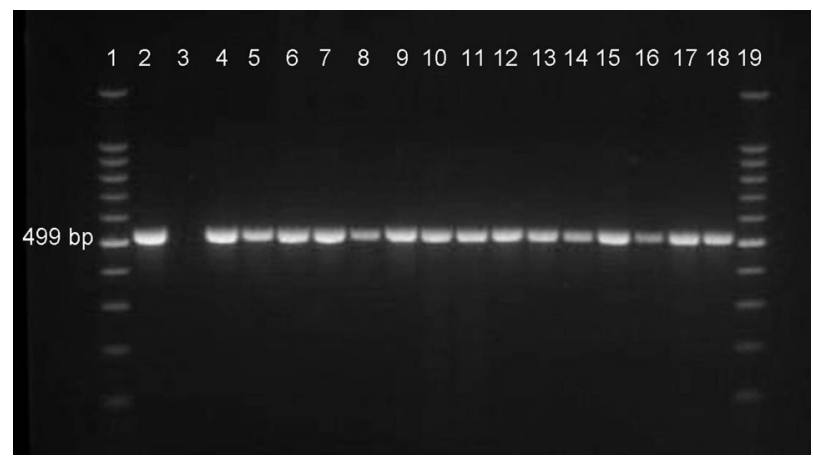

Fig. 4. Panulirus argus. Results of PCR analysis for P. argus Virus 1 (PaV1) infection on spiny lobster. Lanes 1 and 19: 100 bp ladder markers; Lane 2: positive control corresponding to DNA from PaV1; Lane 3: negative control reaction without template DNA; Lanes 4 to 18: $P$. argus tissue sample

\section{DISCUSSION}

This is the first report of PaV1 from lobsters of the Caribbean of Mexico. The 25 juvenile Panulirus argus collected in the reef lagoon of Puerto Morelos with macroscopical signs consistent with those of PaV1 infection showed ultra-structural evidence of this viral infection (Shields \& Behringer 2004). Cowdry Type A intranuclear inclusions and particles with bilayered capsids were observed in all their tissue samples. According to Shields \& Behringer (2004), this viral agent is a presumptive DNA virus with a nucleocapsid size of approximately $182 \pm 9 \mathrm{~nm}$ (mean \pm SD) and nucleoids approximately $118 \pm 4 \mathrm{~nm}$. The presence of PaV1 was further confirmed by PCR by amplification of a 499 bp fragment using the methodology of Montgomery-Fullerton et al. (2007).

A Grade 4 PaV1 infection was found in the hepatopancreatic tissue of all lobsters examined. Viral infections of this severity are considered lethal in viral infections in peneid shrimps (Lightner 1996). Although we cannot attest the same for PaV1 infections, the hepatopancreas had a high amount of Cowdry Type A inclusions and showed severe histopathological changes (J. P. Huchin-Mian et al. unpubl. data).

Although the present study provides the first evidence of infection by PaV1 in wild Panulirus argus outside the Florida Keys, lobsters showing macroscopic signs of PaV1 infection have been regularly observed since 2000 in the Puerto Morelos reef lagoon, and more recently in other locations along the Mexican Caribbean in areas such as Banco Chinchorro and Bahía de la Ascensión (see Fig. 1) (E. Lozano-Álvarez et al. unpubl. data). Therefore, it is possible that other populations throughout the geographic range of $P$. argus might be infected with PaV1.

Due to the high pathogenicity of PaV1, wild populations of Panulirus argus across the Caribbean region should be monitored to determine the distribution and prevalence of this virus, as well as the possibility of genomic differences between geographic locations.

Acknowledgements. We thank CONACyT for providing a postgraduate studentship to J.P.H.M. (Grant 190532). The authors thank F. Negrete-Soto, C. Barradas-Ortiz and C. Pascual-Jiménez for their invaluable technical support. This study was funded by the Programa de monitoreo ambiental del sur del Golfo de México CINVESTAV-IPN Unidad Mérida (Campañas Oceanográficas 2-2005 y SGM No. 10-2005, Xcambó-2. Reference numbers: 428816811 and 418815846).

\section{LITERATURE CITED}

Bell TA, Lightner DV (1987) IHHN disease of Penaeus stylirostris: effects of shrimp size on disease expression. J Fish Dis 110:1165-170 
Li C, Shields JD (2007) Primary culture of hemocytes from the Caribbean spiny lobster, Panulirus argus, and their susceptibility to Panulirus argus Virus 1 (PaV1). J Invertebr Pathol 94:48-55

Lightner DV (1996) A handbook of shrimp pathology and diagnostic procedures for disease of cultured penaeid shrimp. World Aquaculture Society, Baton Rouge, LA

Montgomery-Fullerton MM, Cooper RA, Kauffman KM,

Editorial responsibility: Ken Hasson,

College Station, Texas, USA
Shields JD, Ratzlaff RE (2007) Detection of Panulirus argus Virus 1 in Caribbean spiny lobsters. Dis Aquat Org 76:1-6

Reynolds ES (1963) The use of lead citrate at high pH as an electron-opaque stain in electron microscopy. J Cell Biol $17: 208-212$

Shields JD, Behringer DC Jr (2004) A new pathogenic virus in the Caribbean spiny lobster Panulirus argus from the Florida Keys. Dis Aquat Org 59:109-118

Submitted: September 18, 2007; Accepted: January 21, 2008 Proofs received from author(s): February 26, 2008 